\title{
Characterization of an Effective Salt-tolerant, Fast-growing Strain of Rhizobium japonicum
}

\author{
By M. M. YELTON, ${ }^{1 *}$ S. S. YANG ${ }^{1}$ S. A. EDIE ${ }^{2}$ AND S. T. LIM ${ }^{1,3}$ \\ ${ }^{1}$ Plant Growth Laboratory, University of California, Davis, California 95616, U.S.A. \\ ${ }^{2}$ Department of Agronomy and Range Science, University of California, Davis, California 95616, \\ U.S.A. \\ ${ }^{3}$ Department of Biochemistry, University of Malaya, Kuala Lumpur, Malaysia
}

(Received 8 September 1982; revised 4 November 1982)

\begin{abstract}
Rhizobium japonicum USDA191 is a member of a new group of Rhizobium japonicum strains found in China. This strain is one of several strains shown to be salt-tolerant and fast-growing; it is unique in being the only strain of this group that effectively nodulates American soybean cultivars. For these reasons strain USDA191 was chosen for further study and comparison to the common American Rhizobium japonicum isolate USDA110. Strain USDA191 has a doubling time of $3.2 \mathrm{~h}$ in complex medium and grows in concentrations of up to $0.4 \mathrm{M}-\mathrm{NaCl}$, while strain USDA110, which has a doubling time of $12 \mathrm{~h}$, is severely inhibited in media containing $0 \cdot 1 \mathrm{M}$ $\mathrm{NaCl}$. Under salt stress conditions, intracellular levels of $\mathrm{K}^{+}$and glutamate were shown to increase. A comparison based on carbohydrate metabolism, DNA homology and protein patterns on polyacrylamide gels reveals that strain USDA191 is more closely related to the fastgrowing rhizobia than to Rhizobium japonicum. However, the strain retains capacity to nodulate American soybean and cowpea cultivars effectively.
\end{abstract}

\section{INTRODUCTION}

A survey of strains of Rhizobium japonicum isolated from major production areas in the United States has shown that all the isolates are very sensitive to osmotic stress. Soybeans dependent on symbiotic nitrogen fixation are more salt sensitive than nitrogen-fertilized plants, limiting the soils where symbiotic nitrogen fixation is a useful means of fertilization (Bernstein \& Ogata, 1966). The detrimental effects of salt stress on nodulation, plant growth and nitrogen fixation have been reported for many legumes including alfalfa, peas, mung beans and cowpeas (Balasubraminiam \& Sinha, 1976; Upchurch \& Elkan, 1977; Wilson \& Norris, 1970: Yadav \& Vyvar, 1971). The presence of high sodium chloride has been reported to reduce the number of rhizobia in legume inoculants (Steinborn \& Roughly, 1974, 1975). Tolerance to salt stress may be an important part of saprophytic competence and competitiveness in rhizobia.

Rhizobium japonicum 191 is a member of a salt-tolerant group of $R$. japonicum recently described by Keyser et al. (1982). Strain 191 stands out among this group because it is the only one of this group which forms effective nodules on U.S. cultivars of soybeans. Keyser $e t$ al. (1982) point out that these strains seem similar to the fast-growing group of Rhizobium which are generally more salt-tolerant and produce an acid reaction when grown on mannitol media as opposed to sensitivity to $0.085 \mathrm{M}-\mathrm{NaCl}$ and an alkali reaction on mannitol media characteristic of slow-growing Rhizobium japonicum and Rhizobium spp. (cowpea). However, little further is known about the similarities strain 191 has with the fast-growing group or the mechanism involved in salt tolerance. We report here studies done on the characterization of this unique strain of Rhizobium japonicum and offer a preliminary step to understanding salt tolerance in Rhizobium. 


\section{METHODS}

Bacterial strains and growth conditions. Rhizobium japonicum 110 was obtained from D. F. Weber, USDA, Beltsville, Md. Rhizobium japonicum 191 and R. meliloti 102F28 were obtained from J. C. Burton of the Nitragin Corp., Milwaukee, Wis. Strain 191 was isolated from nodules of 'Jupiter' soybeans (Glycine max) inoculated with soil 'A' obtained from Shanghai, China. Cultures were checked for uniform colony morphology using a Tween 40 medium (Lim, 1978) followed by repeated streaking for isolated colonies on mannitol/salts/yeast extract (MSY medium) plates containing bromothymol blue (Trinick, 1980; Vincent, 1970) to prevent the isolation of genetically mixed colonies.

Minimal media used for growth rate experiments contained glutamate $\left(1 \cdot 0 \mathrm{~g}^{-1}\right)$ and the appropriate carbon source $\left(4.0 \mathrm{~g} \mathrm{l}^{-1}\right)$ unless otherwise indicated, as previously described (Trinick, 1980; Vincent, 1970). The pH of the medium was adjusted to 6.8 prior to autoclaving. The osmotic strength of the medium was increased by the addition of sodium chloride. Cultures were grown aerobically at $30^{\circ} \mathrm{C}$.

Determination of growth rates. Liquid cultures were started using a $2 \%$ inoculum $\left(A_{420}=0 \cdot 1,1 \mathrm{~cm}\right.$ length path) and incubated in a rotary shaker at $30^{\circ} \mathrm{C}$. Growth was followed by measuring the absorbance at $420 \mathrm{~nm}$ in a Gilford model $300 \mathrm{~N}$ spectrophotometer and also by the increase in cell protein, as described by Scott et al. (1979). Total protein was routinely assayed by the Lowry method using bovine serum albumin as a standard. Growth curve data were plotted on semilogarithmic paper and the mean generation times were obtained from the exponential phases of the growth curves.

Utilization of carbohydrates. Strains were tested for growth against each of 18 different carbohydrates. Cultures were grown in minimal media to the mid-exponential phase of growth, washed twice, and resuspended in sterile distilled water. A sample of each of the cultures $(0.1 \mathrm{ml})$ (containing approx. $1 \times 10^{8}$ cells) was spread on plates containing the appropriate filter-sterilized carbon source $\left(4.0 \mathrm{~g} \mathrm{I}^{-1}\right)$. The nitrogen source used was $\mathrm{KNO}_{3}$ $\left(1.0 \mathrm{~g} \mathrm{l}^{-1}\right)$. The plates were incubated at $30^{\circ} \mathrm{C}$ for $7 \mathrm{~d}$ and compared with control plates containing no carbon source.

Determination of intracellular potassium levels. The strains to be tested were grown in minimal medium (lactate/ aspartate) containing the appropriate concentrations of $\mathrm{NaCl}$ in the medium. A $2 \mathrm{ml}$ sample of each of the cultures were placed into test tubes in ice for protein determination. Portions $(1 \mathrm{ml})$ were extracted for potassium analysis according to the method of Epstein \& Schultz (1965). The samples were analysed as previously described (Sanui \& Pace, 1968).

Enzyme assays. Acetylene reduction and hydrogen evolution in air by nitrogenase were determined under linear conditions on detached root systems as described by Bethlenfalvay \& Phillips (1977). The relative efficiency (RE) was calculated as $\mathrm{RE}=1-\left(\mathrm{H}_{2}\right.$ evolution $/ \mathrm{C}_{2} \mathrm{H}_{2}$ reduction) (Schubert \& Evans, 1976). Hydrogenase activity was determined by the tritium uptake assay as previously described (Lim, 1978).

Glucose-6-phosphate dehydrogenase (EC 1.1.1.49, D-glucose-6-phosphate : NADP+ 1-oxidoreductase) and 6phosphogluconate dehydrogenase (EC 1.1.1.44, 6-phospho-D-gluconate : NADP+ 2-oxidoreductase) activities were determined in crude cell-free extracts essentially as described by Martinez De-drets \& Arias (1972). Assay mixtures contained $0.05 \mathrm{~mm}-\mathrm{NADP}+, 0.5 \mathrm{~mm}-\mathrm{MgSO}_{4}, 0.05 \mathrm{~mm}$ glucose-6-phosphate or 6-phosphogluconate (Na salt) and $80 \mathrm{~mm}$-Tris $/ \mathrm{HCl} \mathrm{pH} 8.0$. All assays were carried out at $25^{\circ} \mathrm{C}$.

Polyacrylamide gels of Rhizobium japonicum. The method of Laemmli (1970), as previously described by Scott et al. (1979), was used for one-dimensional gel analysis.

DNA reassociation analysis. DNA was purified from $15 \cdot 1 \mathrm{~g}$ of cells grown in MSY medium, washed twice with $0.85 \%(\mathrm{w} / \mathrm{v}) \mathrm{NaCl}$ and the cell pellet stored at $-20{ }^{\circ} \mathrm{C}$. Cells were resuspended in a minimal amount of lysis buffer

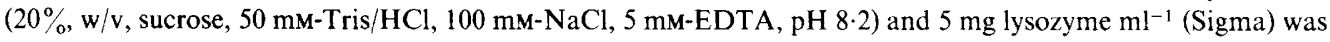
added to initiate cell lysis. Cells were incubated for $30 \mathrm{~min}$ on ice. The lysate was brought to $0.5 \%(\mathrm{w} / \mathrm{v}) \mathrm{SDS}$ using $20 \%$ (w/v) SDS-lysis buffer stock, followed by the addition of $10 \mu \mathrm{g}$ RNAase $\mathrm{ml}^{-1}$ (Sigma) and incubated at $37^{\circ} \mathrm{C}$ for $24 \mathrm{~h}$. The lysate was extracted once with phenol/chloroform $(1: 1, \mathrm{v} / \mathrm{v})$ and twice with chloroform. The sample was run twice on a $49 \%(\mathrm{w} / \mathrm{v}) \mathrm{CsCl}$ gradient at $47 \mathrm{~K}$ r.p.m., $25^{\circ} \mathrm{C}$ in a VTI-65 Beckman rotor until equilibrium was reached $\left(0.5 \mathrm{mg}\right.$ ethidium bromide $\mathrm{ml}^{-1}$ was added to enable monitoring of the DNA banding). The DNA was removed with a 20 gauge needle, ethidium bromide removed by mixing three times with equal volume of isoamyl alcohol followed by extensive dialysis against TNE buffer $(10 \mathrm{~mm}-\mathrm{Tris} / \mathrm{HCl}, 10 \mathrm{~mm}-\mathrm{NaCl}, 1 \cdot 0 \mathrm{~mm}-\mathrm{EDTA}$ $\mathrm{pH} 7 \cdot 5)$. A $1 \mathrm{mg}$ sample of this DNA was diluted to $100 \mathrm{ml}$ in $60 \%(\mathrm{w} / \mathrm{v})$ glycerol, $0.3 \mathrm{M}$-sodium acetate $\mathrm{pH} 5.0$ and sheared to an average strand size of 580 nucleotides in a VirTis 60 homogenizer followed by precipitation with $1 \cdot 1$ vol. isopropanol at $-20^{\circ} \mathrm{C}$ for $12 \mathrm{~h}$. The DNA was collected by centrifugation for $30 \mathrm{~min}$ at $23000 \mathrm{~g}$. The DNA pellet was dried under vacuum and resuspended in TNE to a concentration of $1 \mathrm{mg} \mathrm{ml}^{-1}$. Alternatively, unsheared DNA was nick-translated using the method of Rigby et al. (1977) with ${ }^{3} \mathrm{H}-\mathrm{TTP}$ or ${ }^{32} \mathrm{P}-\mathrm{TTP}$ to a specific activity of $2.0 \times 10^{7}$. Fold back sequences were removed by low $C_{0} t$ incubation followed by hydroxyapatite fractionation. Reassociation analysis was performed essentially according to Britten et al. (1974) and has been described in detail (Timberlake et al., 1977). In general, radioactively labelled DNA was reassociated with a large excess of unlabelled sheared DNA by denaturing samples and incubating to various $C_{0} t$ values (mol nucleotides 
$\mathrm{I}^{-1} \mathrm{~s}$ ) at either $60^{\circ} \mathrm{C}$ in $0.12 \mathrm{M}$-phosphate buffer or at $68^{\circ} \mathrm{C}$ in $0.41 \mathrm{M}$-phosphate buffer. The fractions of bound or unbound DNA were determined by scintillation counting. To determine the $T_{m}$ and relative mismatch of the duplex DNA, gradual melting of the duplexes was observed by monitoring elution of tracer DNAs. Tracer and driver DNAs were incubated to a $C_{0} t$ of 470 or greater and the sample was placed on a hydroxyapatite column, remaining single stranded DNA removed by extensive washing with $0 \cdot 12 \mathrm{M}$-phosphate buffer at $60{ }^{\circ} \mathrm{C}$. Points were taken by raising the column temperature at intervals of $3{ }^{\circ} \mathrm{C}$ and collecting fractions until no further counts were being eluted or counts stabilized at a low level. At $99^{\circ} \mathrm{C}$ all DNA was denatured and completely eluted.

Plasmid analysis. Stationary phase cells $(30 \mathrm{ml})$ grown in mannitol/salts/yeast (MSY) media were harvested by centrifugation and resuspended in $70 \mu \mathrm{l}$ buffer (Triton X-100 5\% (w/v); $15 \%$ sucrose; $50 \mathrm{~mm}$-Tris/ $\mathrm{HCl} \mathrm{pH} 8.5$ and $50 \mathrm{~mm}-\mathrm{Na}_{2}$-EDTA). A $5 \mu \mathrm{l}$ portion of lysozyme $\left(5 \mathrm{mg} \mathrm{ml}^{-1}\right.$, Sigma) was added to the above buffer, and cells were incubated on ice for $1 \mathrm{~min}$ followed by incubation for $1.5 \mathrm{~min}$ at $100^{\circ} \mathrm{C}$, then cooling on ice. The suspension was spun $10 \mathrm{~min}$ in a micro-centrifuge (Fisher model $235-\mathrm{A})$. The supernatant $(\simeq 70 \mu \mathrm{l}$ ) was transferred to a new tube and isopropanol precipitated at $-20^{\circ} \mathrm{C}$ for $16 \mathrm{~h}$ as described above. The precipitated plasmids were collected by centrifuging at $4{ }^{\circ} \mathrm{C}$ for $30 \mathrm{~min}$. The pellet was drained thoroughly and resuspended in $20 \mu 110 \mathrm{mM}-\mathrm{Tris} / \mathrm{HCl}$ $\mathrm{pH} 7 \cdot 5,1 \mathrm{~mm}-\mathrm{Na}_{2}$ EDTA, $1 \mathrm{mg} \mathrm{RNAaseA} \mathrm{ml}{ }^{-1}$ (Sigma). A portion $(10 \mu \mathrm{l})$ of the sample was run on $0 \cdot 8 \%(\mathrm{w} / \mathrm{v})$ agarose gel in $40 \mathrm{~mm}$-Tris $/ \mathrm{OH} ; 20 \mathrm{~mm}$-acetic acid; $2 \mathrm{~mm}-\mathrm{Na}_{2}$ EDTA pH 8.1 . Gels were stained with $0.5 \mu \mathrm{g}$ ethidium bromide $\mathrm{ml}^{-1}$ for $30 \mathrm{~min}$ before observation with UV light (Fig. 4).

Plant nodulation experiments. Rhizobium japonicum 110 and 191 were checked for effectiveness on Clark soybean (Glycine max L. Merr.), cowpea (Vigna unguiculata WALP), 'California blackeye' and alfalfa (Medicago sativa), peas (Pisum sativum L.), and other soybean cultivars (Harosoy, Dixon and the Chinese cultivar, Peking). Seeds were surface sterilized by washing with $95 \%$ ethanol, incubating $5 \min$ in $0 \cdot 1 \%(\mathrm{w} / \mathrm{v}) \mathrm{HgCl}_{2}$ followed by extensive washing with sterile distilled water. Plants were grown under control conditions (Williams \& Phillips, 1980) in 1 litre modified Leonard jar assemblies (DeJong \& Phillips, 1981). The light intensity in the growth chamber had a photon flux density of $650 \mu \mathrm{E}^{-2} \mathrm{~s}^{-1}$. Plants were grown without combined nitrogen and harvested $28 \mathrm{~d}$ after planting. Appropriate positive controls were included in inoculation of identical plants.

Strains were reisolated from the nodules and checked for purity and authenticity by (i) their inability to grow on trypticsoy-agar (Difco) at $37^{\circ} \mathrm{C}$; (ii) morphology and growth characteristics in different media; (iii) serology with antisera against strains 110 and 191 prepared as previously described (Hua et al., 1981); (iv) phage susceptibility tests (Vincent, 1977); (v) the presence of antibiotic markers where marked strains were used.

\section{RESULTS}

\section{Survey of Rhizobium japonicum strains from the major soybean production areas for osmotic} tolerance

A random survey of the osmotic (salt) tolerance capacity of Rhizobium japonicum isolates from soybean production areas in the U.S. has been done, and with results from 12 representative strains tested from nine soybean-producing states, only those from Ohio and Iowa were capable of growth at greater than $0 \cdot 1 \mathrm{M}-\mathrm{NaCl}$. No strains were capable of growth at $0 \cdot 3 \mathrm{M}-\mathrm{NaCl}$.

From the collection of $R$. japonicum isolates from China provided by Dr J. C. Burton, we identified an osmotic tolerant strain designated 191. The growth rates of strain 191 and the common U.S. strain 110 in the presence of various $\mathrm{NaCl}$ concentrations is summarized in Table 1. With no salt added, the doubling time for 191 was $3 \cdot 2 \mathrm{~h}$ while the doubling time for 110 was $12 \mathrm{~h}$. Strain 110 grew poorly at $0 \cdot 075 \mathrm{M}-\mathrm{NaCl}$ and did not grow at $0 \cdot 1 \mathrm{M}-\mathrm{NaCl}$. Rhizobium japonicum 191 was still able to grow in the presence of $0.4 \mathrm{M}-\mathrm{NaCl}$ although at diminished growth rates. These results show that strain 191 is not only more osmotic tolerant, but also grows faster than strain 110 in minimal and $\mathrm{NaCl}$ supplemented media. Doubling times of $4.0 \mathrm{~h}, 4.0 \mathrm{~h}$ and $6.9 \mathrm{~h}$ were obtained for strain 191 in three minimal media that varied in carbon source, Lglutamate-mannitol, glutamate-succinate and aspartate-lactate, respectively. Strain 110 gave doubling times of $15.2 \mathrm{~h}, 16.0 \mathrm{~h}$ and $12.4 \mathrm{~h}$ in these same media, respectively. A fast growth rate is usually associated with an acid reaction in a mannitol medium (Vincent, 1977). Rhizobium japonicum 191 growing in such a medium has been reported to lower the $\mathrm{pH}$ from 6.8 to 5.2 (Keyser et al., 1982) in contrast to the slow-growing Rhizobium which usually give an alkaline reaction.

\section{Nature of osmotic tolerance of Rhizobium japonicum 191}

When exposed to increased osmolarity in their growth medium, many micro-organisms adapt by elevating the intracellular osmotic tension. In certain Gram-negative bacteria, this is 
Table 1. Growth rates of $R$. japonicum 191 and 110 in MSY medium with various concentrations of sodium chloride

Cultures were grown in MSY medium as described in Methods. Growth was followed both by the increase in absorbance at $420 \mathrm{~nm}$ and the increase in cellular protein $\left(\mu \mathrm{g} \mathrm{ml}^{-1}\right)$. Values are the average of three experiments.

\begin{tabular}{lcc}
$\mathrm{NaCl}_{(\mathrm{M})}$ & \multicolumn{2}{c}{ Doubling time $(\mathrm{h})$} \\
0.00 & 191 & $\begin{array}{c}\text { Strain } \\
110\end{array}$ \\
0.05 & $3 \cdot 5$ & $12 \cdot 0$ \\
0.075 & $\mathrm{ND}$ & $16 \cdot 0$ \\
0.1 & $\mathrm{ND}$ & $36 \cdot 0$ \\
0.2 & $4 \cdot 0$ & $\mathrm{NG}$ \\
0.4 & $5 \cdot 3$ & \\
0.6 & $17 \cdot 0$ &
\end{tabular}

ND, not determined; NG, no growth.

Table 2. Intracellular $\mathrm{K}^{+}$levels in Rhizobium species under normal and $\mathrm{NaCl}$ stressed conditions $\mathrm{K}^{+}$levels were determined as described in Methods. Values are the average of three experiments.

\begin{tabular}{|c|c|c|c|}
\hline \multirow[b]{2}{*}{$\begin{array}{c}\mathrm{NaCl} \\
(\mathbf{M})\end{array}$} & \multicolumn{3}{|c|}{ Intracellular $\mathrm{K}^{+}$level [nmol (mg protein $)^{-1}$ ] } \\
\hline & $\begin{array}{c}\text { R. japonicum } \\
110\end{array}$ & $\begin{array}{c}\text { R. japonicum } \\
191\end{array}$ & $\begin{array}{l}\text { R. meliloti } \\
102 \mathrm{~F} 28\end{array}$ \\
\hline 0.00 & 423 & 575 & 263 \\
\hline 0.05 & 533 & ND & ND \\
\hline $0 \cdot 1$ & NG & ND & ND \\
\hline 0.2 & & 758 & 503 \\
\hline 0.4 & & 900 & 838 \\
\hline
\end{tabular}

ND, Not determined; NG, no growth.

Table 3. Enzyme activities in cell-free extracts of rhizobia Activities are expressed as nmol NADP reduced $\min ^{-1}(\mathrm{mg} \text { protein })^{-1}$.

\begin{tabular}{lcc}
\multicolumn{1}{c}{ Strain } & $\begin{array}{c}\text { Glucose-6- } \\
\text { phosphate }\end{array}$ & $\begin{array}{c}\text { 6-Phosphogluconate } \\
\text { dehydrogenase }\end{array}$ \\
$\begin{array}{l}\text { Rhizobium japonicum } \\
191\end{array}$ & $18 \cdot 15$ & $4 \cdot 16$ \\
110 & $1 \cdot 21$ & $<0 \cdot 05$ \\
$\begin{array}{l}\text { Rhizobium meliloti } \\
\text { 102F28 }\end{array}$ & 11.75 & 6.96
\end{tabular}

accomplished by increasing the internal concentration of $\mathrm{K}^{+}$and amino acids (Measures, 1975). The response of the steady state levels of $\mathrm{K}^{+}$in three Rhizobium strains during growth under salt stress is shown in Table 2. Rhizobium japonicum 191 and $R$. meliloti $102 \mathrm{~F} 28$ respond similarly to $\mathrm{NaCl}$, increasing their intracellular $\mathrm{K}^{+}$levels when the $\mathrm{NaCl}$ concentration in the medium is elevated. In the presence of $0.4 \mathrm{M}-\mathrm{NaCl}$, internal $\mathrm{K}^{+}$levels increased to $900 \mathrm{nmol}(\mathrm{mg}$ cell protein) ${ }^{-1}$ in strain 191, as shown in Table 2 . In the case of $R$. japonicum 110 , intracellular $\mathrm{K}^{+}$ levels did not show a significant increase, and $0 \cdot 1 \mathrm{M}-\mathrm{NaCl}$ was toxic to the organism. Under osmotic stress, intracellular glutamate levels were found to increase in $R$. japonicum 191. For example, amino acid analysis of the cell lysate showed that in the presence of $0.2 \mathrm{M}-\mathrm{NaCl}$, glutamate levels in strain 191 increased fivefold (data not shown). This is consistent with the findings of the Hua et al. (1982) who showed increased glutamate levels under salt stress in the Rhizobium sp. WR 1001 . 


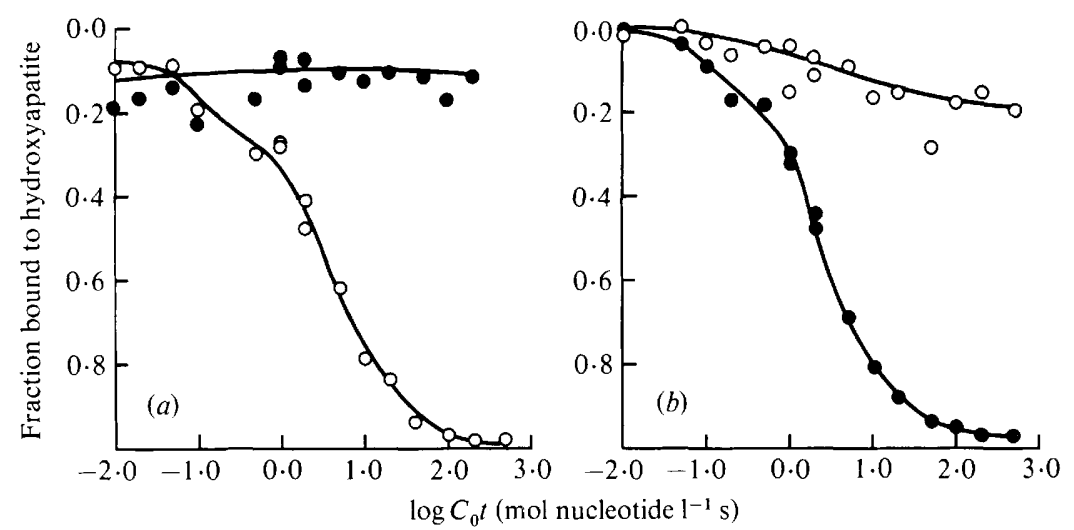

Fig. 1. Kinetics of hybridization of Rhizobium japonicum DNA. $O, R$. japonicum $191 ; \boldsymbol{O}$, $R$. japonicum 110. (a) $R$. japonicum 191 was the driver DNA incubated to indicated $C_{0} t$ values with $R$. japonicum 191 and 110 tracer DNA. (b) The converse experiment where $R$. japonicum 110 was the driver DNA.

\section{Utilization of carbon sources}

We have further characterized the strain 191 with respect to carbon sources for growth. Fastgrowing strains of Rhizobium (e.g. R. meliloti, R. leguminosarum, $R$. trifolii and $R$. phaseoli) generally can use a much wider range of carbon sources than the more fastidious slow growers [R. japonicum, Rhizobium spp. (cowpea)] (Graham, 1964; Graham \& Parker, 1964). Strain 191 resembles $R$. meliloti $102 \mathrm{~F} 28$ in the type and range of carbon sources utilizing all carbon sources tested except dulcitol. Test carbon sources include: maltose, lactose, L-rhamnose, D-glucose, sucrose, D-mannose, galactose, D-fructose, sorbitol, D-xylose, L-arabinose, dulcitol, trehalose, sodium succinate, sodium fumarate, sodium malate and sodium citrate. Strain 191 is clearly different from $R$. japonicum 110 , which utilized a more restricted range of carbon sources and cannot grow on maltose, lactose, cellobiose, sucrose, dulcitol and trehalose. These sugars are thus useful for the identification and classification of these strains.

\section{Glucose-6-phosphate and 6-phosphogluconate dehydrogenases}

Martinez De-drets \& Arias (1972) have shown that fast- and slow-growing Rhizobium can also be differentiated by the levels of carbohydrate catabolic enzymes such as glucose-6-phosphate dehydrogenase and 6-phosphogluconate dehydrogenase. Rhizobium japonicum 191 possesses both these enzymes while only glucose-6-phosphate dehydrogenase is present in strain 110 (Table 3). In this respect, strain 191 resembles the fast grower $R$. meliloti more than the slowgrowing strains which lack 6-phosphogluconate dehydrogenase $\left(\mathrm{NADP}^{+}\right)$.

\section{DNA homology}

DNA homology has been used by many workers to confirm the relationships between the fastand slow-growing strains (Crow et al., 1981 ; Gibbins \& Gregory, 1972; Jarvis et al., 1980). DNA hybridization curves between $R$. japonicum 191 and 110 are shown in Fig. 1 . Approximately $98 \%$ of the strain 191 DNA was associated with the strain 191 driver DNA after incubation at greater than $C_{0} t 2$ (Fig. $1 a$ ). However, only about $15 \%$ of the 110 DNA hybridized to the 191 driver DNA. Similar results were obtained in the converse experiment when 110 DNA was used as the driver (Fig. $1 b$ ). Genomes of the two strains were determined to be of similar size by comparison of $C_{0} t 1 / 2$.

Experiments to determine the melting temperature where $50 \%$ of the duplex DNA is denatured $\left(T_{m}\right)$ and relative mismatch of the duplex DNA from $R$. japonicum 191 and 110 were also performed. The 191/191 DNA duplex formed stable hybrids while the 191/110 DNA hybrid was unstable, allowing for a mismatch of $25 \%$ (Fig. $2 a$ ). Similar results (Fig. $2 b$ ) were obtained in the converse experiment. The $T_{m}$ values from these experiments of $96 \cdot 5$ for $R$. japonicum 191 and 94.5 for $R$. japonicum 110 indicate a difference in $\mathrm{G}+\mathrm{C}$ content of $9 \cdot 3 \%$. 


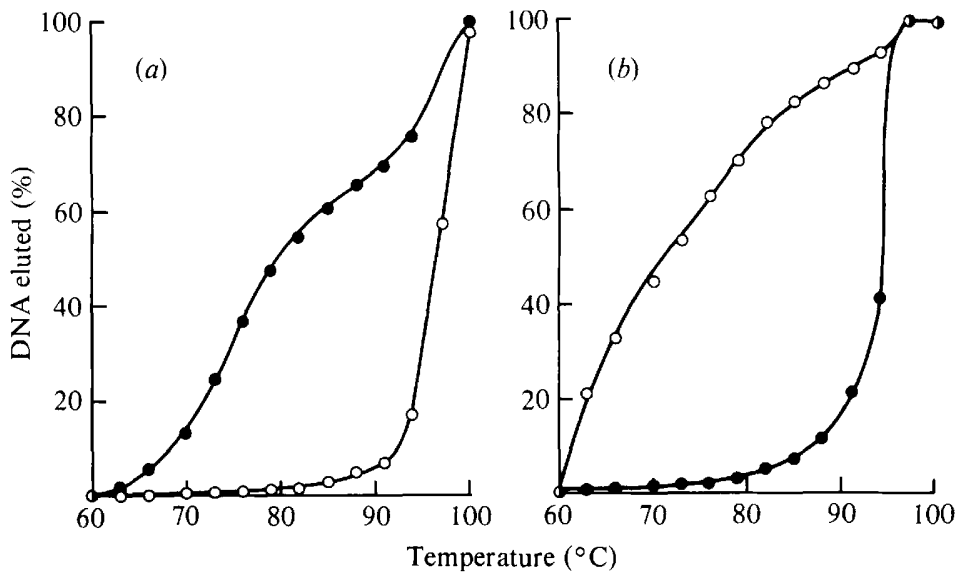

Fig. 2. Melting profile of $R$. japonicum DNA to determine $T_{m}$ (temperature where $50 \%$ of the duplex DNA is denatured) and relative mismatch of duplex DNA. $O, R$. japonicum $191 ;$, $R$. japonicum 110. (a) $R$. japonicum 191 was the driver DNA allowed to hybridize with both $R$. japonicum 191 and 110 tracer DNA. (b) The converse experiment where $R$. japonicum 110 was the driver DNA.

A $\quad$ B

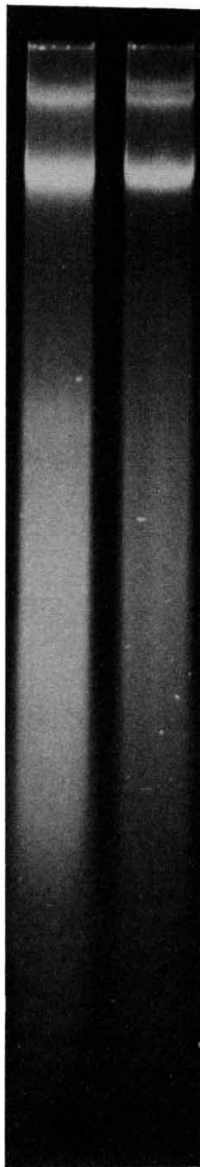

Fig. 3. Agarose gel electrophoresis of plasmid DNA. A, R. japonicum 191; B, R. meliloti 102F28. 


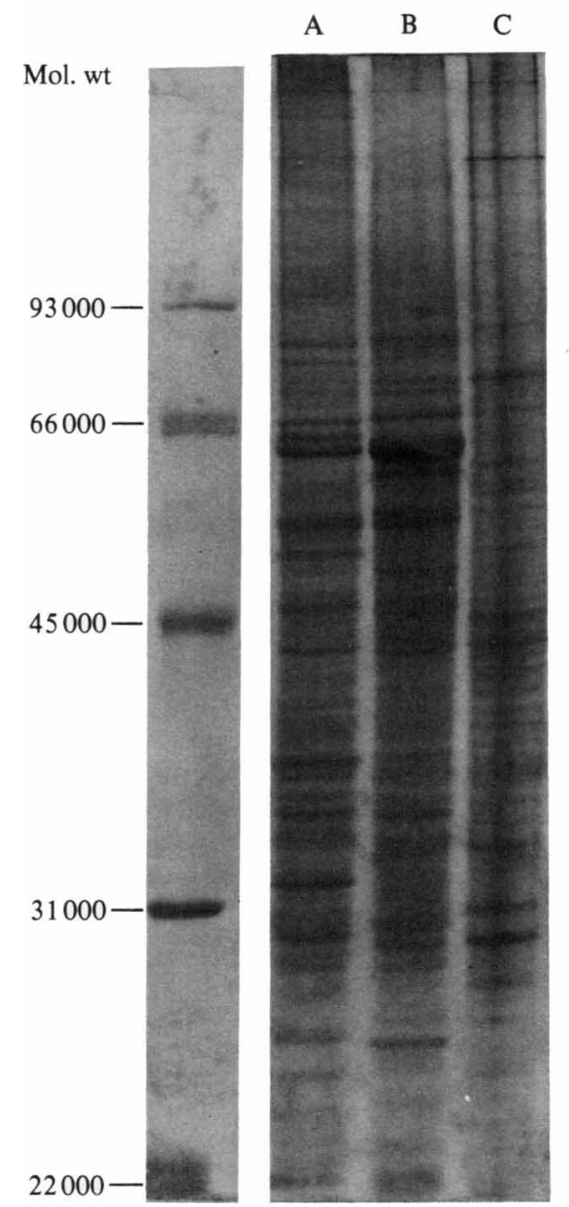

Fig. 4. SDS-PAGE of cell-tree extracts of rhizobia. Approximately $7 \mathrm{mg}$ protein is in each lane, the gel is $10 \%$ polyacrylamide. A, $R$. meliloti $102 \mathrm{~F} 28 ; \mathrm{B}, R$. japonicum $191 ; \mathrm{C}, R$. japonicum 110 . Molecular weight standards (BioRad) were : phosphorylase B, 92500 : bovine serum albumin, 66200 ; ovalbumin, 45000; carbonic anhydrase, 31000 ; soybean trypsin inhibitor, 21500.

\section{Plasmid analysis}

Rhizobium japonicum 191 was shown to have two large plasmids of the same molecular weights as two of the three plasmids found in $R$. meliloti $102 \mathrm{~F} 28$ (Fig. 3). $R$. japonicum 110 appears to have no plasmids under these conditions. Casse et al. (1979) examined the plasmids in $R$. meliloti $102 \mathrm{~F} 28$ and found two plasmids, $73 \pm 4$ and $118 \pm 3 \mathrm{MDal}$. In our study three plasmids were seen in $R$. meliloti $102 \mathrm{~F} 28$, the two larger plasmids are of similar size and could have previously been interpreted as one plasmid. We estimate the plasmids in strain 191 to be of approximately the same size as those in strain 102F 28 . It may be possible that these strains have additional large plasmids which were lost in the plasmid preparation. Additional attempts were made to isolate plasmids by the methods described by Kado \& Kiu (1981) and Davis et al. (1980) without success.

\section{Polyacrylamide gel analysis}

The protein patterns on polyacrylamide gels can give a measure of genetic relatedness between strains as shown by Roberts et al. (1980). Analysis of the protein patterns of cultures of $R$. japonicum 191 and 110 grown aerobically under identical conditions showed that at the gross level there is little similarity in the two-dimensional pattern of protein distribution between these two strains (data not shown). Most of the visible protein patterns in strain 191 were equally 


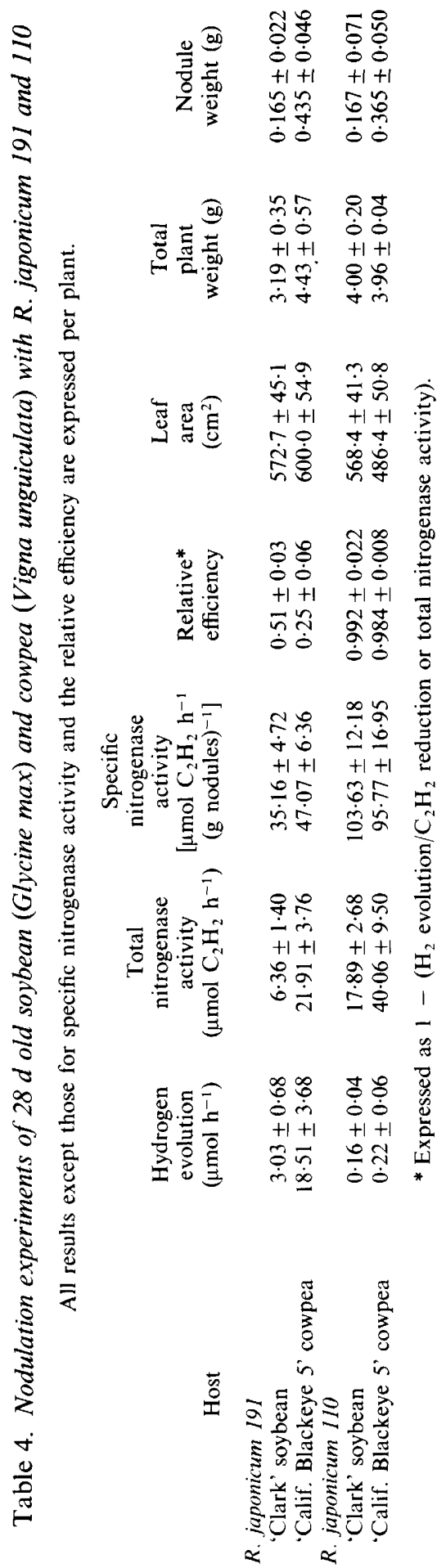


Table 5. Summary of characteristics of Rhizobium 191 and 110

$\begin{array}{ccc} & \text { Strain } & \text { Strain } \\ \text { Characteristic } & 191 & 110\end{array}$

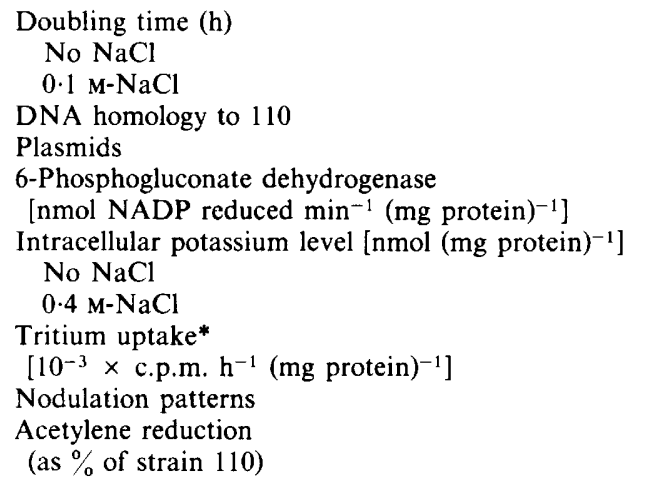

3.5
$4 \cdot 0$
$18 \%$
$2(50-150 \mathrm{MDal})$
3.31
575
900
$<5\left(\right.$ Hup $\left.^{-}\right)$
Soybean and cowpea
$30 \%$

$12 \cdot 0$
No growth
$98 \%$
None found
$<0.05$
423
No growth
$638 \cdot 7$ (Hup ${ }^{+}$)
Soybean and cowpea
$100 \%$

* Value given is the average of three experiments.

distributed between the basic and acidic regions, while those from strain 110 were concentrated in the basic and neutral regions. A few patterns in the high molecular weight basic region may be common to both strains indicating a degree of relatedness between the two strains. This difference can clearly be seen in Fig. 4 on one-dimensional gels. Some similarity can be seen between $R$. japonicum 191 and $R$. meliloti 102F 28 .

\section{Nodulation experiments}

Cross inoculation experiments of 'Clark' soybean (Glycine max) and 'California Blackeye 5' cowpea (Vigna unguiculata) were carried out with $R$. japonicum 191 and 110 . The two strains were shown to be effective on both hosts. Nodules on both the legumes were similar, with an overall appearance much like those of typical $R$. japonicum soybean nodules. Although no major differences were detected in terms of nodule weight, leaf area and total plant weight, the specific nitrogenase activity (acetylene reduction capacity) of strain 191 was approximately $30 \%$ that of strain 110 on both legumes (Table 4). In addition, although $\mathrm{H}_{2}$ evolution was detected from nodules formed by both strains, that from strain 110 was negligible when compared with strain 191. The relative efficiency values (Schubert \& Evans, 1976) of strain 191 on both legumes also indicated that it lacks a hydrogen uptake system $\left(\mathrm{Hup}^{-}\right)$, while strain 110 is $\mathrm{Hup}^{+}$(Table 4), this is confirmed by tritium uptake values (Table 5) on whole cells. A streptomycin $\left(100 \mu \mathrm{g} \mathrm{ml}^{-1}\right)$ resistant strain of 191 also nodulated the Harosoy, Dixon and Peking cultivars effectively. The bacteria isolated from the nodules retained the antibiotic marker and the faster growth rates of the strain used to inoculate the cultivars. Experiments to determine nodulation of pea (Pisum sativum) and alfalfa (Medicago sativa) with $R$. japonicum 191 were negative.

\section{DISCUSSION}

In this paper we have characterized the unusual Rhizobium japonicum strain 191. This new strain has more characteristics in common with the fast-growing groups of Rhizobia than the slow-growing group. The single characteristic that strain 191 has with the common American strain, $R$. japonicum 110 , is the ability to form effective nodules on American soybeans. This nodulation pattern defines strain 191 as $R$. japonicum. The classification of rhizobia based on plant nodulation patterns is a controversial topic. Hollis et al. (1981) suggested that even within the slow-growing $R$. japonicum strains at least three distinct DNA homology groups exist. The discovery of strain 191 further supports the inadequacy of the current classification system since it differs not only by DNA homology, but by several other characteristics, summarized in Table 5 .

Strains such as 191 seem to constitute an intermediate Rhizobium japonicum which, although 
possessing most of the characteristics of the fast growers, has the ability to nodulate soybean and cowpea effectively. Recently, Brewin et al. (1980) and Hooykaas et al. (1981), have shown that genes influencing the host range of $R$. trifolii and $R$. leguminosarum are carried on large plasmids. The nodulation genes on one plasmid may suppress the nodulation genes on a second plasmid (Johnston et al., 1978). These results suggest that a similar situation may have occurred in strain 191 where the two large plasmids present in strain 191 may alter host range.

Due to the fast growth rate and osmotic tolerance, strain 191 would be expected to have a competitive edge for survival in the environment. While the specific activity (acetylene reduction capacity) of strain 191 is only $30 \%$ of strain 110 on both soybeans and cowpea, there is very little difference between the two strains in terms of leaf area, and total plant and nodule weight. The economic value of strain 191, however, must be determined in field trials.

Until recently, researchers have had to choose between working with the more experimentally attractive fast-growing, salt-tolerant strains versus the more economically important slowgrowing $R$. japonicum strains. Strain 191 may now offer a useful system for biochemical and genetic studies of $R$. japonicum in a fast-growing, salt tolerant strain effective on American soybean cultivars.

We would like to thank Dr R. C. Valentine, Dr D. A. Phillips and Dr W. E. Timberlake for helpful discussions. Appreciation is also extended to Ms Sandie Uratsu and Ms Sally Ju for expert technical assistance and Dr J. Meeks for critical reading of the manuscript. This work was supported by NSF grant AER 77-07301. S. T. Lim was supported by the University of Malaya under Vote F 153/79 and 137/80. S. S. Yang was supported by the Ministry of Education of the People's Republic of China.

\section{REFERENCES}

Balasubraminiam, V. \& Sinha, S. K. (1976). Effects of salt stress on growth, nodulation and nitrogen fixation in cowpea and mung bean. Physiologia Plantarum 36, 197-200.

Bernstein, L. \& OGata, G. (1966). Effects of salinity on nodulation, nitrogen fixation and growth of soybean and alfalfa. Agronomy Journal 68, 201-203.

Bethlenfalvay, G. J. \& Phillips, D. A. (1977). Ontogenetic interactions between photosynthesis and symbiotic nitrogen fixation in legumes. Plant Physiology 60, 419-421.

Brewin, N. J., Beringer, J. E. \& Johnston, A. W. B. (1980). Plasmid-mediated transfer of host-range specificity between two strains of Rhizobium leguminosarum. Journal of General Microbiology 120, 413420.

Britten, R. J., Graham, D. E. \& Neufeld, B. R. (1974). Analysis of repeating DNA sequences by reassociation. Methods in Enzymology 29, 363-418.

Casse, F., Boucher, C., Julliot, J. S., Michel, M., \& DÉNARIÉ, J. (1979). Identification and characterization of large plasmids in Rhizobium meliloti using agarose gel electrophoresis. Journal of General Microbiology 113, 229-242.

Davis, R., Botstein, D. \& Roth, J. R. (1980). Rapid plasmid isolation from a $10 \mathrm{ml}$ culture. In Advanced Bacterial Genetics, pp. 124-125. New York: Cold Spring Harbor Laboratory.

Crow, V. L., JARVIS, B. D. W. \& GreENWOOD, R. M. (1981). DNA homologies among acid-producing strains of Rhizobium. International Journal of Systematic Bacteriology 31, 152-172.

DeJong, T. M. \& Phillips, D. A. (1981). Nitrogen stress and apparent photosynthesis in symbiotically grown Pisum sativum L. Plant Physiology 68, 309313.

Epstein, W. \& Schultz, S. G. (1965). Cation transport in Escherichia coli. V. Regulation of cation content. Journal of General Physiology 49, 221-234. (No. 1, part I1)

Gibbins, A. M. \& Gregory, K. F. (1972). Relatedness among Rhizobium and Agrobacterium species determined by three methods of nucleic acid hybridization. Journal of Bacteriology 111, 129-141.

GraHAM, P. H. (1964). Studies on the utilization of carbohydrates and Krebs cycle intermediates by Rhizobia using an agar plate method. Antonie van Leeuwenhoek 30, 68-72.

Graham, P. H. \& Parker, C. A. (1964). Diagnostic features in the characterization of the root-nodule bacteria of legumes. Plant and Soil 20, 383-396.

Hollis, A. B., Kloos, W. E. \& ElkaN, G. H. (1981). DNA:DNA hybridization studies of Rhizobium japonicum and related Rhizobiaceae. Journal of General Microbiology 123, 214-222.

HooykaAs, P. J. J., VAN Bressel, A. A. N., DEN DulK Ras, H., van Sloyteren, G. M. S. \& SCHILPEROORT, R. A. (1981). Sym plasmid of Rhizobium trifolit expressed in different rhizobial species and Agrobacterium tumefaciens. Nature, London 291, 351-353.

Hua, S. S., ScotT, D. B. \& LiM, S. T. (1981). A mutant of Rhizobium japonicum with elevated levels of $\mathrm{Nif}$ activity in free-living cultures. In Genetic Engineering of Symbiotic Nitrogen Fixation and Conservation of Fixed Nitrogen, pp. 95-105. Edited by J. M. Lyons, R. C. Valentine, D. A. Phillips, D. W. Rains \& R. C. Huffaker. New York: Plenum Press.

Hua, S. T., Tsai, V. Y., Lichens, G. M. \& Noma, A. T. (1982). Accumulation of amino acids in Rhizobium sp. strain WR110 in response to sodium chloride salinity. Applied and Environmental Microbiology 44, $135-140$.

JAR Vis, B. D. W., Dick, A. G. \& Greenwood, R. M. (1980). Deoxyribonucleic acid homology among 
strains of Rhizobium trifolii and related species. International Journal of Systematic Bacteriology 30, $42-52$.

Johnston, A. W. B., Beynon, J. L., BuchananWollaston, A. V., Setchell, S. M., Hirsch, P. R. \& BERINGER, J. E. (1978). High frequency transfer of nodulation ability between strains and species of Rhizobium. Nature, London 276, 634 636.

KaDo, C. I. \& LUI, S.-T. (1980). Rapid procedure for detection and isolation of large and small plasmids. Journal of Bacteriology 145, 1365-1373.

Keyser, H. H., BohloOl, B. B., Hu, T. S. \& Weber, D. F. (1982). Fast-growing Rhizobia isolated from root nodules of soybean. Science 215, 1631-1632.

LAEMMLI, U. K. (1970). Cleavage of structural proteins during the assembly of the head of bacteriophage T4. Nature, London 227, 680-685.

LIM, S. T. (1978). Determination of hydrogenase in free-living cultures of Rhizobium japonicum and energy efficiency of soybean nodules. Plant Physiology 62, 609-611.

Martinez De-Drets, G. \& Arias, A. (1972). Enzymatic basis for the differentiation of Rhizobium into fast and slow-growing groups. Journal of Bacteriology 109, 467-470.

Measures, J. C. (1975). Role of amino acids in osmoregulation of non-halophilic bacteria. Nature, London 257, 298-400.

Rigby, P. W., Dieckmann, M., Rhodes, C. \& Berg, R. (1977). Labeling deoxyribonucleic acid to high specific activity in vitro by nick translation with DNA polymerase 1. Journal of Molecular Biology 113, 237-251.

Roberts, G. P., LePS, W. T., Silver, L. E. \& Brill, W. J. (1980). Use of two-dimensional polyacrylamide gel electrophoresis to identify and classify Rhizobium strains. Applied Environmental Microbiology 29, 414422.

SANUi, H. \& PACE, N. (1968). Chemical and ionization interference in the atomic absorption spectrophotometric measurement of sodium, potassium, rubidium and cesium. Analytical Biochemistry 25, 330346.

Schubert, K. R. \& EvanS, H. J. (1976). Hydrogen evolution: a major factor affecting the efficiency of nitrogen fixation in nodulated legumes. Proceedings of the National Academy of Sciences of the United States of America 73, 1207-1211.

Scott, D. B., Hennecke, H. \& Lim, S. T. (1979). The biosynthesis of nitrogenase MoFe protein polypeptides in free-living cultures of Rhizobium japonicum. Biochimica et biophysica acta 565, 365-378.

SteinborN, J. \& Roughly, R. J. (1974). Sodium chloride as a cause of low numbers of Rhizobium in legume inoculants. Journal of Applied Bacteriology 37, 93-99.

Steinborn, J. \& Roughly, R. J. (1975). Toxicity of $\mathrm{Na}^{+}$and $\mathrm{Cl}^{-}$to Rhizobium spp. in broth and peat cultures. Journal of Applied Bacteriology 39, 133-138.

Timberlake, W. E., SHumard, D. S. \& GoldberG, R. B. (1977). Relationship between nuclear and polysomal RNA populations of Achlya: a simple eucaryotic system. Cell 10, 623-632.

TRINICK, M. J. (1980). Relationships amongst the fastgrowing Rhizobia of Lablab purpureus, Leucaena levcocephala, Mimosa spp, Acacia farnesiana and Sesbania grandiflora and their affinity with other rhizobial groups. Journal of Applied Bacteriology 49, 39-53.

UPChURCh, R. G. \& ElKan, G. H. (1977). Comparison of colony morphology, salt tolerance and effectiveness in Rhizobium japonicum. Canadian Journal of Microbiology 23, 1118-1122.

VinCENT, J. M. (1970). A Manual for the Practical Study of Root-nodule Bacteria. Oxford: Blackwell Scientific Publications.

VINCENT, J. M. (1977). Rhizobium: general microbiology. In $A$ Treatise on Dinitrogen Fixation, (section 111), pp. 277-366. Edited by R. W. F. Hardy \& W. S. Silver. New York: John Wiley.

Williams, L. E. \& Phillips, D. A. (1980). Effect of irradiance on development of apparent nitrogen fixation and photosynthesis in soybean. Plant Physiology 66, 968-972.

WILSON, J. R. \& NORRIS, D. O. (1970). Some effects of salinity on Glycine javanica and its Rhizobium symbiosis. Proceedings of the 11th International Grasslands Conference, pp. 455-458.

YADAV, M. K. \& VYVAS, S. R. (1971). Response of rootnodule rhizobia to saline, alkaline and acid conditions. Indian Journal of Science 41, 875-881. 